Dunamis: Jurnal Teologi dan Pendidikan Kristiani

Volume 3, Nomor 2 (April 2019)

ISSN 2541-3937 (print), 2541-3945 (online)

http://www.sttintheos.ac.id/e-journal/index.php/dunamis

Submitted: 29 Desember 2018

Accepted: 22 April 2019

Published: 29 April 2019

\title{
An Analysis of Economic Wealth of God's People from Nomadic to Post Exilic Era
}

\author{
Halim Wiryadinata \\ Sekolah Tinggi Teologi Pelita Bangsa, Jakarta \\ ketua@sttpb.ac.id
}

\begin{abstract}
The terminology of the economic wealth is not actually related to the poor in terms of poverty and wealth in the Bible. The terminology of wealth and poverty is not a matter of relationship to the business or economy, but they are rather to have relationships to seek the righteousness of God. Thus, one should clarify the meaning of wealth and poverty in order to seek the real meaning of the Old Testament theology. The eras of Nomadic to Post Exilic give the idea of how God dealt with the people of God in term of sinful nature. It is not the matter of the economic situation, but it is blessedness for the people who seek Him with all their heart. Nomadic era gives an idea of how God gives the promise land to the people of Israel as long as they can keep the covenant. However, throughout the history the Israelites never entered into the promise land, except Caleb and Joshua. The picture of Babylonia is the wrath of God to the people of Israel who never listen to the command of God. In conclusion, seeking God with full heart will find 'rest' forever and keep the promise forever more. Keeping the righteousness of God will bring justice to the poor and let the poverty be away from the poor.
\end{abstract}

Keywords: Economy; Nomadic; Post Exilic; Wealth; God's people 


\section{INTRODUCTION}

Provisions of God for His people are abounding to the obedient of His people to His Law. Walter Kaiser comments, "Even before any technical vocabulary about entering into a covenant appeared, God promised to enter into a relationship with Abraham and thereby to be and to do something for Abraham that would benefit both him and all nations of the earth." ${ }^{1}$ It seems that God will provide His provision to His people according to His promise in the covenant. Therefore, the economic wealth of God's people seems to be in the line of the obedient of His people to the covenant that He had made for His people through the patriarch. If this is so, then it leads people to see the background of economy itself in the light of the subject economy and it will apply to the covenant.

After we see the understanding of the word 'economy', then we will see how economy to be seen from the perspective of Theology and social dimension in order to see how our premise will come out as the theory or not. Therefore, the next section is to see economy in the perspective of Theology, then to see economy in the light of social dimension.

\section{Economy and its Terminology}

\footnotetext{
${ }^{1}$ Walter C. Kaiser, Toward An Old Testament Theology (Michigan: Zondervan Publishing House, 1978), 86.
}

P. Dicken has introduced to the world with the new terminology "Global Shift" in the world economy. ${ }^{2}$ The term of global shift has been coined by one author to capture the essence of the change. People seem to be witnessing the globalization of markets and productions. With the regard to the globalization of markets, it has been argued that we are moving away from an economic system in which national markets are distinct entities, isolated from each other by trade barriers and barriers of distance, time and culture and toward as system in which national markets are merging into one huge global marketplace. ${ }^{3}$

According to this view, the tastes and preferences of consumers in different nations are beginning to converge on some global norm. Thus, in many industries it is no longer meaningful to talk about the "German market", "the American market," or "Japanese market"; there is only the "global market'. In other words, the global economy is one in which goods, services, people, skills, and ideas move freely across geographic borders. 5 Therefore, globalization is the spread of economic

\footnotetext{
${ }^{2}$ P. Dicken, Global Shift (New York: Guilford, 1992), 5.

${ }^{3}$ Charles W. Hill, International Business (USA: w Hill Companies, 1999), 5.

${ }^{4}$ T Levitt, "The Globalization of Markets," Harvard Business Review (1983), 92-102.

${ }^{5}$ R. Murtha, T. P., Lenway, S. A., and Bagozzi, "Global Mind-Sets and Cognitive Shifts in a Complex Multinational Corporation," Strategic Management Journal 19 (1998), 97-114.
} 
innovations around the world and the political and cultural adjustment that company this diffusion. Globalization encourages international integrations, which has increased substantially during the last generation. ${ }^{6}$

Looking at the terminology of the word 'economy' today, it associates strongly to the world globalization. Put it into another words, economy today applies to the meaning globally and affects to the whole world. If it applies to the Christian Bible, it will apply to the meaning of 'blessings of God' among His people. It is rightly when Walter Kaiser sees that the word of promise in the Patriarchal Era gives the evidence. ${ }^{7} \mathrm{He}$ sees that, "The content of this promise was basically threefold: a seed, a land and a blessing to all the nations of the earth." ${ }^{, 8}$ In the book of Genesis 12: 23, there are the words of blessings and promise that God gave to Abraham. The promise of God to Abraham are: "I will make you a great nation", "I will bless you", and "I will make your name great."

Here is the connection between the word 'economy' and 'blessing' appears globally. The promise of God upon His people applies globally as the word of

\footnotetext{
Michael Ireland Hitt, R. Duane, and Robert E. Hoskisson, Strategic Management Competitiveness and Globalization (USA: South Western College Publishing, 2001), 12-15.

${ }^{7}$ Kaiser, Toward An Old Testament Theology, 86.

${ }^{8}$ Ibid.
}

economy today is in the stage of global shift. ${ }^{9}$ However, there are God's statements of cursing when He sees upon the mistakes of His people. God says in Genesis 12:3, "I will bless those who bless you" and "I will curse those who curse you". If it is seen beyond the promise, actually Israel was given by God the land of Canaan in God's blueprint. The promise of the land of Canaan to Abraham, Isaac, Jacob and their seed are found in Genesis 12:7; 13:15; 15: 7-8, 18; 24: 7; 26: 3-5 and 28: 23-14.

The word of globally economy has the meaning of the word of globally blessings to His people when the people seek Him and obey Him. Abraham also in the Genesis account received the first part of what was to become the oft-repeated of the promise. The divine oath of God to Abraham was "I will be a God to you and to your seed." The promise and blessing are the same components when people seek Him with the righteousness. Abraham at the end of his life was called 'the Friend of God" in James 2: 23. The word economy, finally, has the meaning of blessing for Christian people when they seek God alone. It seems to be supported by the Oxford Dictionary when it says, "Economy is the economic system of the country" which people can see globally effect to the whole people. As a result of, the

\footnotetext{
${ }^{9}$ H. C. Leupold., Exposition of Genesis 2 (Grand Rapids: Baker Book House, 1968), 411.
} 
Bible has the word 'blessings' applies to the people of God.

\section{Ancient Israel and The Perspective of}

\section{Religious Practice; Socio - Economy and}

\section{Political Development}

Norman Gottwald assumes that religious practice is the most important role in influencing the economy, socio - culture and political development in ancient Israel. ${ }^{10}$ This view also is supported by Saul M. Olyan when he sees that the cult centralization and its sociopolitical implications through lenses of kingship and gender. ${ }^{11}$ Looking at the political development, politics in the pre - state Israel were embedded and decentralized, not forming an autonomous network but operative as a type of activity spread variously throughout the other network. Politics in colonial Israel were split and displaced into a commanding imperial centre beyond Israel's control and a subservient colonial periphery her political activity was circumscribed but nonetheless real. In other words, the basic dynamics of colonial Israel is based as much or more on the Persian and Hellenistic imperial policies in general terms than on internal evidence about Judah. If this

\footnotetext{
${ }^{10}$ Norman Gotwaldd, The Politics of Ancient Israel (Kentucky: Westminster John Knox Press, 2001), 1020.

${ }^{11}$ Saul M Olyan, Social Theory and The Study of Israelite Religion (Atlanta: Society of Biblical Literature, 2012),1-2.
}

is so, it applies that the pre-exilic Israelites religion seems to force that the cult of Yahweh was neither dominant enough nor sufficiently unified in its diverse manifestation to shape the politics of Israelites state in decisive manner. ${ }^{12}$ This view also can be seen that Israelites people never managed to develop a political structure that matched the creativity and novelty of the culture and religion they produced. Their form of rule should be accordant with the religious ideals and respectful of ordinary of Judahites, they never developed a conception or model of political order as a viable alternative to the tributary or imperial state. Put it into another way, ancient Israel's politics have repeatedly mined for the support of the divine right of kings, revolution against unjust authority, covenant - based commonwealths, liberal democracy, religious nationalism, anarchism, capitalism and socialism. ${ }^{13}$ If we compare to modern state of Israel, therefore, it applies that there is no to recuperate a coherent biblical politics that can resolve the conflicting claims of religious nationalism and liberal democracy.

\footnotetext{
${ }^{12}$ Nissim Amzallag, "Yahweh, the Canaanite God of Metallurgy?," Journal for the Study of the Old Testament 33, no. 4 (June 11, 2009): 387-404, accessed January 16, 2018, http://journals.sagepub.com/doi/10.1177/0309089209 105686.

${ }^{13}$ Gotwaldd, The Politics of Ancient Israel, 57.
} 
In the comparative social studies, it is apparently bound up on the public power network to any single society such as ancient Israel. It is also needed to see that the Old Testament makes clear that the Israelites were nomadic, pastoral people probably until the period in which they conquered and settled in Canaan. Most pastoralists did not wander long distances, but rather engaged in transhumance. This means that Israelites used landscape, combining highland summer pastures, lowland winter pastures and watering holes or oases along the route. Gottwald assumes that the book of Nehemiah 5 was the best example of Nehemiah's debt reforms. ${ }^{14}$ Then, he goes on in comparing with Solon of Athens and concludes that Solon and Nehemiah wished to quell popular unrest by granting specific economic concessions that did not correct the fundamental inequities of the sociopolitical system. This suggests that Israelites produced the ideology. For Israel, the most explicitly developed form of ideology is religious. Religious practices are very important for Israelites in order to get wealthy from Yahweh. In other words, religion is an active force in the sociopolitical and socio cultural as a singular prime mover of the course of events.

Accordingly, the ancient Hebrew experience articulated for the first time the principle of the dignity of humankind. In other words, citizens of a given society have rights that are inalienable, even before the authority of a king. By confronting the development of religious matters and more specifically as the betrayal of the ancestral covenant with Yahweh, the reforming prophets are able to reassert authority in Israel in respect to religious reforms in order to reject idolatry, sacrifice and polytheism. As a result, ancient Israel and the perspective of religious practice, socio - economy and political development are bound up on the religious matters among the Israelites. To sum up, religious practices determine the action of socio - cultural, economy and political development. In other words, the acknowledging Yahweh in their religious practices is one of the fundamental way to gain the economy, socio - cultural and politics.

\section{METHOD}

This is an article with a qualitative approach used a descriptive and analysis methodology. For a comprehensive picture of God's people and the relation of economy, an approach of the Old Testament theology was required here.

\section{RESULT}

Old Testament Theology (Ethical Theology) and Economy Perspective

\footnotetext{
${ }^{14}$ Ibid,5.
} 
From it has been said above, it leads us to see the Old Testament Theology and Economy perspective. This is so, because these areas are very important to see how the Economic Wealth bounds up together in making a form of blessing from the Almighty God. This section will be divided into several sections in order to see how each era will be seen clearly about the blessings of God to His own people. The first section will discuss the Pre-patriarchal, which will discuss how the beginning will set up the whole theology of blessings. Then, we will discuss the condition of nomadic, kingdoms, division of kingdoms to Post Exilic eras. This section will focus on the area of Ethical Theology, which is considered as to do with human conduct. The special concern of Christian ethics is to relate an understanding of God to the conduct of men and women and, more specifically, to explore the response to God which Jesus Christ requires and makes possible.

\section{Pre-Patriarchal Era}

Walter Kaiser sees that the time of pre-patriarchal must be looked back to the time of Edenic, Noachic and Abrahamic blessing. He argues that the whole of points blessing in the pre-patriarchal era began in the Genesis 1-11, where God Himself promised to bless all created beings. ${ }^{15}$

${ }^{15}$ Kaiser, Toward An Old Testament Theology, 71.
However, Westermann argues that the big themes of the pre-patriarchal era must begin from the Creation, Fall and man's personal sin before the Lord. ${ }^{16}$ Therefore, the differences between those are not going to be a matter as long as the divine blessing of God always pours out to His own people. Looking at the history that God has made and set up for His own people from the creation of this world. In other words, the word creation always follows the word of blessing. This can be looked when the Lord says in Genesis 1: 22, "God blessed them by saying: Be fruitful and multiply and fill the waters of the seas; and let birds multiply on the earth". This blessing applies to the whole creation according to the book of Genesis. However, the word of blessing also is followed with the word of cursing especially disobedient.

In Genesis 9: 25-27, there is the word of cursing on Canaan. In verse 25, God says, "And he said, cursed be Canaan; A servant of servants will he be to his brothers." Then the word of blessing too appears in verses 26 and 27 when God says, "And He said, Blessed be the Lord God of Shem; Let Canaan be a slave to him. God will enlarge Japhet, But He will dwell in the tents of Shem; Let Canaan be a slave to him." Here the important points that seemingly about the

\footnotetext{
${ }^{16}$ Claus Westermann, Creation (Philadelphia: Fortress Press, 1974), 17-31.
} 
dwelling and blessing happen together. The word 'dwell' also will associate with the word of Mosaic, which is Shekinah Glory of God wherein the presence of God over the tabernacle is evidenced by the pillar of cloud by day and the pillar of fire by night. ${ }^{17}$ This point will lead us to see that the disaster of man's disobedience, the tyrannical distortion of political power and the haughty of unity on a humanistic basis led to the judgment of the Fall, the Flood, the dispersion of mankind. This is then the result of the disobedient of human beings, who are away from the Creator.

The economic situation when the time pre-patriarchal era is bound up on the matter of obedient and disobedient of the people of God. It is very clear that the people, who are obedient, will be part of the covenant, while others will be cut off. This brings the idea of provision of God upon the world. In other words, the idea of provision of God in the Christian doctrine rests not upon such metaphysical speculation, but on the teaching of the Bible. ${ }^{18}$ The providence of God displays his benevolence (Mat. 5: 45), especially to the believer, who is comforted to be told that all things work together for his good. Therefore, in this

\footnotetext{
${ }^{17}$ Kaiser, Toward An Old Testament Theology, 71-82.

18 Adam Gregerman, "Superiority without Supersessionism: Walter Kasper, The Gifts and the Calling of God Are Irrevocable, and God's Covenant with the Jews," Theological Studies 79, no. 1 (2018): 36-59.
}

doctrine that the sovereign character of God becomes the ground of practical hope to all who trust in Him. The blessing in the economy also can be seen in the light of mankind. People were blessed in the field (Gen. 4: 1-2) and in cultural advance of respecting one another (vv. 17-22). The development of blessing is considered highly in the area of the Old Testament.

\section{Patriarchal Era (Nomadic) and Economy \\ Perspective}

Looking at the Patriarchal era, people will be led into the provision that has been promised in the time of pre-patriarchal era. This can be seen that the Old Testament is set within the context of the covenant. It leads people to see God's love for his people and the psalmists extol law keeping as a powerful means of expressing his people's love for them. (Psalm 19: 7-11; 119: 33-36, 72).

According to Kaiser, this era was an absolutely premium era, because God poured out His abundance blessing and promise in the Genesis 12-50. ${ }^{19}$ The blessing that people could see was divided into threefold. First, it was the seed, then the land and the blessing to all nations of the earth. The blessing for all nations, it can truly be seen from Abraham (Gen. 12:3; 18:18; 22:17-18), Isaac (Gen. 26:3-4) and Jacob (Gen. 28:13-14). This blessing for the world-wide was the

\footnotetext{
${ }^{19}$ Kaiser, Toward An Old Testament Theology, 86.
} 
whole purpose of the very first statement of the promise in 12:2-3, which is the key passage for the promising of the nationhood. ${ }^{20}$ To have nationhood, there was a statement of 'counted righteous'.

In Genesis 15, it is about God entering into a covenant with Abraham. He promises him that his seed will be as numerous as the stars in the sky. The passage states that Abraham believed God and it was credited to him as righteousness. Immediately Abraham was told that Yahweh was going to give him the land, and that he was going to take possession of it. Abraham's response was to question God: 'How can I know that I shall take possession of it?" Yahweh's response to this challenge was to inaugurate formally the covenant $\mathrm{He}$ had made with Abram, a covenant that Yahweh took responsibility for and that had been implicitly in existence since Abram had responded to Yahweh's call to leave Ur of the Chaldeans (Genesis 12: 9). In the inaugural ceremony that Yahweh instituted with Abraham in Genesis 15: 6-18, it is obvious that the initiative is entirely God's. Let's look at the quotation from Genesis 15: 6-18: "Abram believed the LORD, and he credited it to him as righteousness. He also said to him, "I am the LORD, who brought you out of Ur of the Chaldeans to give you

\footnotetext{
${ }^{20}$ Tom Holland, Contour of Pauline Theology (Scotland: Christian Focus Publications, 2004), 216217.
}

this land to take possession of it." But Abram said, "Sovereign LORD, how can I know that I will gain possession of it?" So the LORD said to him, "Bring me a heifer, a goat and a ram, each three years old, along with a dove and a young pigeon." Abram brought all these to him, cut them in two and arranged the halves opposite each other; the birds, however, he did not cut in half. Then birds of prey came down on the carcasses, but Abram drove them away. As the sun was setting, Abram fell into a deep sleep, thick and dreadful darkness came over him. Then the LORD said to him, "Know for certain that for four hundred years your descendants will be strangers in a country not their own and that they will be enslaved and mistreated there. But I will punish the nation they serve as slaves, and afterward they will come out with great possessions. You, however, will go to your ancestors in peace and be buried at a good old age. In the fourth generation your descendants will come back here, for the sin of the Amorites has not yet reached its full measure." When the sun had set and darkness had fallen, a smoking fire pot with a blazing torch appeared and passed between the pieces. On that day the LORD made a covenant with Abram and said, "To your descendants I give this land, from the Wadi of Egypt to the great river, the Euphrates."

It is very essential about Yahweh's commitment protecting the promised seed 
from bondage to exile. This is at the heart of what the covenant promised and how the crediting of righteousness should be understood. Here is the promise of the covenant in having the land and being wealth in it. The concept of economy in the nomadic era was the promise of God to Abraham when he was credited to Him as a righteous person. In other words, to be righteous in the eyes of God is the bottom line to have a wealth economy perspective. It is very clear that not only did God continue the promise, but He also introduced a whole class of people who would respond variously to Abraham. Then, the promise of the land of Canaan to Abraham, Isaac and Jacob can be found in Genesis 15: 18. The land of Canaan was to be an 'everlasting possession'. 21 This is then how the economy of wealth has an impact to the life of people in the Nomadic era. The word of righteous is the basic of the point to have an 'everlasting possession' as God made Abraham become the father of all nations, because he was credited as righteous before God.

\section{Settlement Era and Economy Perspective}

From what it has been said above, it leads us to see how the settlement era plays an important role in the economy perspective for the people of God. According to Kaiser, sixty nine times the writer of Deuteronomy

\footnotetext{
${ }^{21}$ Jurgen Moltmann, Theology of Hope (New York: Harper \& Row, 1965), 105.
}

repeated the pledge that Israel would one day 'possess' and 'inherit' the land promised to her. The land was meant here that was the Land of Canaan. If it is further researched, then the land of Canaan and the people of Israel alike were called 'the inheritance'. In other words, the land of Canaan was called the Promised Land and Israel was called the promised people. ${ }^{22}$ Keith W Whitelam, however, argued that if the Land belongs to Yahweh then it is very clear that this notion is of a totally different order from that of the promise of the land to the early patriarchs is hardly to understand. ${ }^{23}$ Kaiser insisted strongly that it was the fact that the Land belonged to Yahweh and there was no mark of syncretism with features of from Canaanite religion. Here is the difference from Yahweh and Baal, where Baal may have regarded as the Lord of the land and the giver of all blessings in pagan Canaanite religion, Yahweh is Lord of all the earth. Therefore, Yahweh gave the land for Israel as a gift and Israel had to possess it. This is then a creation of divine sovereignty and human responsibilities were complementary ideas rather than antithetic pairs.

The economy perspective of the Settlement Era is based on the gift of

\footnotetext{
${ }^{22}$ Scott Hahn, "Covenant in the Old and New Testaments: Some Current Research (1994-2004)," Currents in Research 3, no. 2 (2005): 263-292.

${ }^{23}$ Keith W Whitelam, "Israel's Traditions of Origin: Reclaiming the Land," Journal for the Study of the Old Testament 44 (1989): 19-42.
} 
Yahweh to Israel in possessing the Land of Canaan. However, the complementary ideas play important role for the understanding of the concept of economy perspective in the Settlement Era. The divine sovereignty and human responsibilities must have the same balance for the economic wealth for His people. In other words, in every way the promised inheritance was a delightful gift, which owned by Yahweh and leased to Israel in partial fulfillment of His Word of promise. In this land, Israel was to be blessed (Deut. 15:4; 23:20; 28:8; 30:16), but special emphasis was placed on the blessing of the ground (Deut. 28:8). Thus, the blessing of God again became one of the connecting concepts which united the theology of the earlier periods with that of the pre-monarchical Era. ${ }^{24}$

The idea of blessing of God for Israel inherited the Land of Canaan surely can be seen from the perspective of economy was absolutely plentiful. Israel herself was rested peacefully in the land of Canaan for quite long time. However, there was a teaching that Israel had to choose according to Joshua 21:44-45, says:

The Lord gave them rest on every side just as He had sworn to their fathers. Not one of all enemies had withstood them, for the Lord had given all their enemies into their power. Not one of all the good promises which the Lord had made to the house of Israel failed; all had come to pass.

The emphasis of Joshua 21:44-45 was still on the promised word which had not failed Israel, nor would it. But whether Israel would retain her privilege of remaining in the land was another matter. Israel had to choose between life and death, good and evil. This is the teaching of economy wealth in the Settlement Era where Israel had to choose life and death by obeying one command which summarized all the others: Love the Lord your God. Therefore, the promise of the inheritance of the rest of God was protected even in the event of subsequent sins by the recipient's descendants. Kaiser comments rightly, "Rest was no blank check in which future generations could slide by the standard of God on their father's laurels. This promise was to be theirs only if they would appropriate it by faith - that was the spiritual and immediate benefit of 'rest'.,"25

\section{The Kingdom Era and the Economy \\ Perspective}

After looking at the Settlement Era, this research will focus on the Kingdom Era in the light of the economy perspective. In looking the Kingdom Era, people will keep on their eyes on the promise of 2 Samuel 7, which is focusing on a greater promise, that 
is the history of salvation. This is the idea of economy wealth in the Kingdom Era. The promise of the king for Israel actually has gone far beyond in the time of Deuteronomy 17: 14 , says:

When you come to the land which the Lord your God is giving you and you possess it and dwell in it and then say, I will set a king over me, like all the nations and are round about me; you may indeed set as king over him whom the Lord will choose, one from the midst of your brethren you will set as king over you.

This is then the perfect plan of God, who never forgets of what He plans for. He never left out the idea of kingship. In other words, people are taught to be patience to see the time of God in the right time and right place. Josephus claims that the government of Israel had been labeled a theocracy in which the sovereignty and power belonged to God. ${ }^{26}$ If this is so, then Peabody claims that "Jesus' first demand was not for the orthodox instruction or for ecstatic religious experience but for morality." 27 This view is supported when Klausner said, "If ever the day should come and this ethical code be stripped of its wrappings of miracle and mysticism, the Book of the Ethics of Jesus will be one of the choicest treasures of the

\footnotetext{
${ }^{26}$ Lester L Grabbe, "The Jewish Theocrcy from Cyrus to Titus: A Programmatic Essay," Journal for the Study of the Old Testament 37 (1987): 117-124.

${ }^{27}$ F. G. Peabody, Jesus Christ and Christian Character (Pearson, 1906), 103.
}

literature of Israel for all time., ${ }^{28}$ It seems that the Kingdom Era should be considered between ethical teaching of God and His message about the Kingdom on earth. Therefore, the ethics of the Kingdom places a new emphasis on the righteousness of the heart. $^{29}$

T W Manson insists strongly the ethical teaching of the Testament of the Twelve Patriarchs is a moving demand for an inner righteousness. ${ }^{30}$ Thus, the power of righteousness in inner heart is very important for the time of people in the Kingdom. The essential righteousness of the Kingdom, since it is a righteousness of the heart, is actually qualitatively if not quantitatively. Here it applies the economy of the Kingdom era where God needed the pure heart of the Old Testament people. The people, who did not have a pure heart, would not exist in the kingdom era. This also applies to the New Testament Era, where the teaching of the Lord Jesus Christ especially on the area of ethics is nomistic. That means a righteousness determined by obedience to the commandments and Jesus presupposed an inner renewal that would enable people to

\footnotetext{
${ }^{28} \mathrm{~J}$. Klausener, Jesus of Nazareth (Chicago: Fortress Press, 1925), 414.

${ }^{29}$ George Eldon Ladd, A Theology of the New Testament (Michigan: Williams B. Eerdmans Publishing Company, 1974), 127.

${ }^{30}$ T. W. Manson, Ethics and the Gospel (Michigan: Eerdmans Publishing Company, 1960), 54-63..
} 
fulfill his teaching. ${ }^{31}$ The righteousness of the Kingdom Era, in the light of economy perspective can be experienced only by the one who has submitted to the reign of God (Theocracy) that has been manifested in Jesus, and who has experienced the power of the Kingdom of God.

\section{The Division of Kingdom, Post Exilic Era and the Economy Perspective}

The Division of the Kingdom is the most critical periods in the whole history for the nation of Israel. The critical point is the destruction and the long predicted Babylonian captivity. The Division of the Kingdom was actually predicted and happened in the time of Nahum, Zephaniah, Habakkuk, and Jeremiah. Those prophets were telling about the division of the Kingdom. The flaws in the Old Testament's approach to wealth and poverty, according to Donald E. Gowen, seem to be that it is individualistic and addressed to the righteous. ${ }^{32}$ If one cares nothing about righteousness, no coercions are provided.

In the light of Donald E. Gowen, in the middle of the time of Zechariah especially post exilic Jewish community and also looked back at the reasons for the fall of

\footnotetext{
${ }^{31} \mathrm{H}$. Windisch, The Meaning of the Sermon on the Mount (Leicester: IVP, 1992), 113.

${ }^{32}$ Donald E. Gowen, "Wealth and Poverty in the Old Testament: The Case of the Widow, The Orphan and The Sojourner," in The Best on Theology, ed. J. I. Packer (USA: Christianity Today, 1989), 18.
}

Jerusalem and the Exile, Zechariah could explain in Zecharia 7: 9-10: "Administer true justice; Show loyalty and compassion, each to this brother; Do not defraud the widow and orphan, the sojourner and the poor; And do not devise evil against his brother."

In the time of Post Exilic, poverty was a plight which might occur to any one, but there were certain groups of people who were powerless for reasons in addition to poverty. Therefore, the idea of Division of Kingdoms and Post Exilic Eras on the wealth subject is about to emphasis on the condition of widow, orphan and immigrants as the classic example of the powerless. The final criterion of the Old Testament for determining how adequately wealth was distributed in the land and how much opportunity was offered the poor to better their position was diagnostic. The problem of the Old Testament in the time of Post Exilic Era was to get justice for the poor people. ${ }^{33}$ The condition was to deal with the problems of being hungry and ill-clothed and homeless; but all of them could be thwarted by injustice and it was against which the Old Testament rages.

In other words, care for the poor was the responsibility of the King, as the representative of Yahweh (Psalm 72: 2-4). That is no matter what the economic system may be, no matter whether the region was

\footnotetext{
${ }^{33}$ Ibid, 15.
} 
relatively poor or relatively prosperous, one could judge how good that system is and how well it is administered by considering what becomes of people like widow, people who experience a sudden, involuntary change of fortune for the worse.

\section{DISCUSSION}

\section{Social Dimension of Wealth or Poverty}

In social dimension of wealth and poverty, one should see the social ethics among the people of God. The aim of social ethics is to clarify the understanding values and principles which should inform practical understandings of and responses to social matters. ${ }^{34}$ This will apply to the wealth and poverty, where the Bible focuses not to wealth or poverty as the accumulation or lack of riches as a commodity, but to relationships between people which poverty and wealth express. ${ }^{35}$

The Old Testament concentrates on what it means in economic relationships (Lev. 25), whereas the New Testament the poor replaces Israel as the focus of the Gospel. When God addresses the deformation which human sin brought into the world, he begins with those suffering most deeply from greed, selfishness and the

\footnotetext{
${ }^{34}$ J. W. Gladwin, "Social Ethics," in New Dictionary of Theology, ed. Sinclair Ferguson and David Wright (Leicester: IVP, 1988), 645.

${ }^{35}$ C. M. N. Sugden, "Poverty and Wealth," in New Dictionary of Theology, ed. Sinclair B. Fergusson and David F. Wright (Leicester: IVP Press, 1988), 523.
}

exercise of wrong dominion over others Hebrew migrant laborers in Egypt. The deliverance of God (Exodus 3-5) for Israel was to save Israel, because God focused to make Israel right in the world (Deut. 26: 1$10)$.

To clarify the Mosaic Law was to prevent injustice arising again among the people of God (Deut. 6: 20-25), so that there were no poor among the people of God (Deut 15: 4). Therefore, God made king over His people in order to protect the people of God from exploitation and bring justice to the poor (Isa. 11: 4). Therefore, the issue of poverty and wealth is not about the economic relationships separate from the experience of the Kingdom of God or the proclamation of the Gospel.

The social dimension of wealth and poverty must be based on ethical teaching, which is essentially God - centered. The problem of wealth and poverty is based on how to deal with sins. In other words, a sin soaked world, then the ethical issue becomes an extraordinary complex. Thus, it makes the presence of so much law in the Bible does, in fact, bear its own witness to the theocentric foundation on which Christian ethics is built. $^{36}$

In the New Testament, social dimension is very clear to see, because New

\footnotetext{
${ }^{36}$ D. H. Field, "Ethics," in New Dictionary of Theology, ed. Sinclair B. Fergusson (Leicester: IVP, 1988), 234.
} 
Testament mention about the terms of children, women, Samaritans, social outcasts, the sick, the lost sheep of the house of Israel. If people are proved to be righteous and rich, then they must show the experience of the content of the Gospel and the power of the Gospel must be shown as well. Here is the biblical perspective confronts the view that the poor need the generosity of the wealthy as endless receivers aids. Rather the wealthy need the poor, to learn from them the nature and meaning of the deliverance God brings to both. The basis of sharing is when those separated by distorted relationships discovers that they both equally need each other.

The relationships between the wealthy people and poor people are the main focus for the Old Testament and the New Testament. Even though sin becomes the separation, but God Himself wants the wealthy people should help the poor people in order to show the power of the Gospel. In the social dimension, wealthy and poverty is very clear to show the audiences about how the relationships must be tight together in showing the Gospel of the Lord Jesus Christ.

\section{An Analysis of the Economic Wealth from the Nomadic to Post Exilic Eras}

After looking at the economic wealth throughout the Old Testament era especially from the Pre - Patriarch, Nomadic,
Kingdoms, Division of Kingdoms and Post Exilic eras, then one could see how wealth and poverty work together for the life of the people in the Old Testament. When people see the life of pre - patriarch, then sin is the only matter of God wanted to deal with. Therefore, the history of Israel went to Egypt and they were in the time of trouble there. Even though, the ruling government of God was a theocracy, but the doctrine of $\sin$ provides the most powerful analysis of life as we know it today. While it was in the time of Kingdoms, then the role of King was to give assistance to the poor and bring justice to uphold the rights of the poor. The Old Testament, according to Sugden, was to eliminate the life of poverty and give justice to the poor. ${ }^{37} \mathrm{He}$ also supports that the New Testament especially in the life of Jesus focused on the matter of the poor ( 2 Cor. 8 : 9). The ministry of Jesus was with the sick, the Samaritans. Those branded as 'sinners' and the socially rejected. ${ }^{38}$ Sugden seems quite true when he sees that the relationship of the wealth and poverty is not the matter of the economic condition, but it is rather about the relationships experiencing the Kingdom of God or the proclamation of the Gospel.

When one should see from the perspective of theology and social dimension, so one could conclude that the

\footnotetext{
${ }^{37}$ See Sugden, op. cit., p. 523.

${ }^{38}$ Ibid.
} 
real barrier of the Israelites people never come into the promised - land, because of the $\sin$. It was very obvious indeed when Israelites people never entered the Canaan, only two people could experience the promise of God for Israelites. If this is the picture of the Old Testament, then the picture of the New Testament is more less the same. When the Lord Jesus Christ came into the world, He did not deal with the poor in term of economic situation, but it was rather to deal with sin in order to give an upright life of the poor. ${ }^{39}$

\section{CONCLUSION}

In conclusion, the economic wealth in the Old Testament is actually on the matter seeking God fully with the heart of the people. The history from the Nomadic to Post Exilic is the matter of sin, where people were lead into the exile. Babylonia was the picture of the wrath of God to the people of Israel, who never listened to God. Therefore, the people of Israel were sent to Babylonia. In contrast, when people seek God with fully of their heart, it is certainly that God will bless them as He blessed Joshua and Caleb in entering the promise land. Finally, sin must be removed in order to be blessed and seek righteousness from God to have a better life. Wealth and poverty are not a matter of economic terminology, but they are

${ }^{39}$ Cf. Sugden, op. cit., p. 524. relationships in the salvation of God. For the righteousness of God, it is an absolutely magnificent construction as genitive grammar in the Greek New Testament. It is a prominent area to consider seeing how the redemption of the Messiah has already given the righteousness of God (or the covenant faithfulness of God to His people) to be revealed. The righteousness of God cannot be separated with the work of the Messiah upon the Cross, because it brings us in order to see how truthful and faithful our God is to His covenant to redeem us to be His people.

\section{REFERENCES}

Amzallag, Nissim. "Yahweh, the Canaanite God of Metallurgy?" Journal for the Study of the Old Testament 33, no. 4 (June 11, 2009): 387-404. Accessed January 16, 2018. http://journals.sagepub.com/doi/10.117 7/0309089209105686.

Dicken, P. Global Shift. New York: Guilford, 1992.

Field, D. H. "Ethics." In New Dictionary of Theology, edited by Sinclair B. Fergusson. Leicester: IVP, 1988.

Gladwin, J. W. "Social Ethics." In New Dictionary of Theology, edited by Sinclair Ferguson and David Wright. Leicester: IVP, 1988.

Gotwaldd, Norman. The Politics of Ancient Israel. Kentucky: Westminster John Knox Press, 2001.

Gowen, Donald E. "Wealth and Poverty in the Old Testament: The Case of the Widow, The Orphan and The Sojourner." In The Best on Theology, edited by J. I. Packer. USA: Christianity 
Today, 1989.

Grabbe, Lester L. "The Jewish Theocrcy from Cyrus to Titus: A Programmatic Essay." Journal for the Study of the Old Testament 37 (1987): 117-124.

Gregerman, Adam. "Superiority without Supersessionism: Walter Kasper, The Gifts and the Calling of God Are Irrevocable, and God's Covenant with the Jews." Theological Studies 79, no. 1 (2018): 36-59.

Hahn, Scott. "Covenant in the Old and New Testaments: Some Current Research (1994-2004)." Currents in Research 3, no. 2 (2005): 263-292.

Hill, Charles W. International Business. USA: w Hill Companies, 1999.

Hitt, Michael Ireland, R. Duane, and Robert E. Hoskisson. Strategic Management Competitiveness and Globalization. USA: South Western College Publishing, 2001.

Holland, Tom. Contour of Pauline Theology. Scotland: Christian Focus Publications, 2004.

Kaiser, Walter C. Toward An Old Testament Theology. Michigan: Zondervan Publishing House, 1978.

Klausener, J. Jesus of Nazareth. Chicago: Fortress Press, 1925.

Ladd, George Eldon. A Theology of the New Testament. Michigan: Williams B. Eerdmans Publishing Company, 1974.
Leupold., H. C. Exposition of Genesis 2. Grand Rapids: Baker Book House, 1968

Levitt, T. "The Globalization of Markets." Harvard Business Review (1983).

Manson, T. W. Ethics and the Gospel. Michigan: Eerdmans Publishing Company, 1960.

Moltmann, Jurgen. Theology of Hope. New York: Harper \& Row, 1965.

Murtha, T. P., Lenway, S. A., and Bagozzi, R. "Global Mind-Sets and Cognitive Shifts in a Complex Multinational Corporation." Strategic Management Journal 19 (1998).

Olyan, Saul M. Social Theory and The Study of Israelite Religion. Atlanta: Society of Biblical Literature, 2012.

Peabody, F. G. Jesus Christ and Christian Character. Pearson, 1906.

Sugden, C. M. N. "Poverty and Wealth." In New Dictionary of Theology, edited by Sinclair B. Fergusson and David F. Wright. Leicester: IVP Press, 1988.

Westermann, Claus. Creation. Philadelphia: Fortress Press, 1974.

Whitelam, Keith W. "Israel's Traditions of Origin: Reclaiming the Land." Journal for the Study of the Old Testament 44 (1989): 19-42.

Windisch, H. The Meaning of the Sermon on the Mount. Leicester: IVP, 1992. 